\title{
Effects of Antibiotics on Fibrinolytic Activity
}

\author{
Isamu OKUNO, Yumi FUJIHARU and Kiyohisa UCHIDA \\ Shionogi Research Laboratories, Shionogi \& Co.. Ltd.. \\ Fukushima-ku, Osaka 553, Japan \\ Accepted July 7, 1986
}

\begin{abstract}
Latamoxef, cefamandole, carbenicilin and cefotaxime were examined for their effects on fibrinolytic activity in vitro by means of the fibrin plate method, fibrin clot lysis time and euglobulin lysis time with human, rabbit and rat plasma. These antibiotics showed no fibrinolytic but weak antifibrinolytic activity at 1000 or $3000 \mu \mathrm{g} / \mathrm{ml}$ in some assay systems.
\end{abstract}

Antibiotics have been reported to cause bleeding in some severely ill patients $(1,2)$, and although the mechanism is not yet known, a disorder of the vitamin $K$ dependent coagulation system $(3,4)$ and platelet dysfunction $(5,6)$ are suspected causes. Enhancement of fibrinolysis also causes bleeding (7), but the effect of antibiotics on fibrinolytic activity is not yet known. In this study, we examined the effects of some antibiotics on fibrinolytic activity in vitro by means of the fibrin plate method, fibrin clot lysis time and euglobulin lysis time. Latamoxef (LMOX) and cefotaxime (CTX) from the third generation, cefamandole (CMD) from the second, and carbenicillin (CBPC) from penicillin-type antibiotics were chosen, and the results with these compounds were compared with those for some reference compounds.

6-Amino- $n$-caproic acid (EACA) and trans(aminomethyl)cyclohexanecarboxylic acid (AMCHA) were purchased from Nakarai Chemicals (Japan), sodium dextran sulfate from Pharmacia (Sweden), urokinase (UK) from Green Cross Co. (Japan). and fibrinogen from Seikagaku Kogyo (Japan). All the test compounds and euglobulin fractions were dissolved in $0.12 \mathrm{M}$ acetate buffer $(\mathrm{pH}$ 7.4) unless otherwise mentioned.

Fibrin plates were prepared by the method of Norén et al. (8) and the effects of antibiotics and EACA on fibrinolytic activity of UK were examined using plasminogencontaining fibrin plates. The test compounds were dissolved in $0.1 \mathrm{ml}$ of $0.01 \mathrm{M}$ phosphate buffer $(\mathrm{pH} 7.8)$ in various concentrations and mixed with $0.1 \mathrm{ml}$ of UK saline solution (75 $\mathrm{U} / \mathrm{ml})$. An aliquot $(5 \mu \mathrm{l})$ of the mixture was put into wells ( $3 \mathrm{~mm}$ in diameter) on the fibrin plates. The lysis area was measured after incubation at $37^{\circ} \mathrm{C}$ for $20 \mathrm{hr}$.

EACA inhibited the UK activity by $20 \%$ (lysis area) at the final concentration of 2000 $\mu \mathrm{g} / \mathrm{ml}\left(1.5 \times 10^{-2} \mathrm{M}\right)$, but LMOX, CMD. CBPC and CTX showed no inhibition at the concentrations of $0.64-2000 \mu \mathrm{g} / \mathrm{ml}$.

Fibrin clot lysis time was measured with an aliquot (350 $\mu$ ) of human fibrinogen solution, which was enriched with $2.5 \mathrm{\mu g}$ of bovine plasminogen, transferred to a polystyrene tube, mixed in sequence with $50 \mu$ of UK solution $(20 \mathrm{U} / \mathrm{ml}), 50 \mu$ of the test compound solution and $50 \mu l$ of thrombin solution $(20 \mathrm{U} / \mathrm{ml})$, and incubated at $37^{\circ} \mathrm{C}$ in a water bath. The time for complete lysis of the formed fibrin clot was measured (Table 1). LMOX and CBPC showed no effect on the fibrin lysis time, but it was increased significantly by DMD at $1000 \mu \mathrm{g} / \mathrm{ml}$ and CTX at $3000 \mu \mathrm{g} / \mathrm{ml}$. EACA prolonged the fibrin clot lysis time at $100 \mu \mathrm{g} / \mathrm{ml}$ and AMCHA prolonged it at $30 \mu \mathrm{g} / \mathrm{ml}$, confirming the report of Westlund et al. (9).

The effects of antibiotics on euglobulin lysis time were examined by preparing euglobulin fractions from human, rabbit and rat plasma according to the method of Kluft et al. (10). An aiiquot (400 $\mu l)$ of the euglobulin solution was mixed with $50 \mu$ of 
the test compound solution and $50 / 1$ of thrombin solution $(25 \mathrm{U} / \mathrm{ml})$ in a polystyrene test tube and incubated at $37^{\circ} \mathrm{C}$ for up to $600 \mathrm{~min}$. Euglobulin lysis time was taken as the interval between addition of thrombin and complete lysis of the formed clot. As shown in Table 2, LMOX, CMD and CTX prolonged the euglobulin lysis time at $1000 \mu \mathrm{g} / \mathrm{ml}$, and CBPC prolonged it at $3000 \mu \mathrm{g} / \mathrm{ml}$. EACA also increased the lysis time at $10 / \mathrm{g} / \mathrm{ml}$, but UK decreased the time at $0.3 \mathrm{U} / \mathrm{ml}$. When rabbit euglobulin was used, the responses of EACA and UK were weaker than those with human euglobulin, and rat euglobulin gave weaker results than rabbit euglobulin. This species difference in the response agrees with the antifibrinolytic activities disclosed upon addition of UK to rat, rabbit and human whole

Table 1. Effects of some substances on fibrinolytic activity based on fibrin clot lysis time (min)

\begin{tabular}{lcccccc} 
& No. of & & \multicolumn{5}{c}{ Concentration } \\
E. experiments & 0 & 100 & 300 & 1000 & 3000 \\
Latamoxef $(\times 1 \mu \mathrm{g} / \mathrm{ml})$ & 3 & $87 \pm 7^{*}$ & $88 \pm 7$ & $90 \pm 7$ & $98 \pm 5$ & $121 \pm 10$ \\
Cefamandol $(\times 1 \mu \mathrm{g} / \mathrm{ml})$ & 4 & $88 \pm 5$ & $91 \pm 5$ & $100 \pm 6$ & $117 \pm 6^{*}$ & $211 \pm 20^{*}$ \\
Carbenicillin $(\times 1 \mu \mathrm{g} / \mathrm{ml})$ & 3 & $89 \pm 7$ & $90 \pm 7$ & $92 \pm 7$ & $94 \pm 7$ & $99 \pm 7$ \\
Cefotaxime $(\times 1 \mu \mathrm{g} / \mathrm{ml})$ & 3 & $86 \pm 6$ & $87 \pm 6$ & $91 \pm 7$ & $106 \pm 7$ & $171 \pm 19^{*}$ \\
EACA $\left(\times 10^{-1} \mu \mathrm{g} / \mathrm{ml}\right)$ & 4 & $98 \pm 5$ & $89 \pm 4$ & $94 \pm 5$ & $115 \pm 7^{*}$ & $194 \pm 7^{*}$ \\
AMCHA $\left(\times 10^{-2} \mu \mathrm{g} / \mathrm{ml}\right)$ & 4 & $88 \pm 5$ & $91 \pm 4$ & $93 \pm 5$ & $105 \pm 6$ & $143 \pm 8^{*}$ \\
Streptokinase $\left(\times 10^{-3} \mathrm{U} / \mathrm{ml}\right)$ & 4 & $91 \pm 5$ & & $53 \pm 4$ & $32 \pm 1^{*}$ & $22 \pm 0^{*}$ \\
Dextran sulfate $\left(\times 10^{-4} \mu \mathrm{g} / \mathrm{ml}\right)$ & 4 & $90 \pm 5$ & & $74 \pm 7$ & $61 \pm 6^{*}$ & $51+4^{*}$ \\
\hline
\end{tabular}

EACA, 6-amino-n-caproic acid. AMCHA, trans-4-(aminomethyl)cyclohexanecarboxylic acid. aMean \pm S.E. *Statistically significant difference compared with 0 concentration $(P<0.05)$.

Table 2. Effects of latamoxef, cefamandole, carbenicillin and cefotaxime on euglobulin lysis time in human, rabbit and rat plasma

\begin{tabular}{|c|c|c|c|c|c|c|}
\hline & \multirow{2}{*}{$\begin{array}{c}\text { No. of } \\
\text { experiments }\end{array}$} & \multicolumn{5}{|c|}{ Concentration } \\
\hline & & 0 & 100 & 300 & 1000 & 3000 \\
\hline \multicolumn{7}{|l|}{ Human } \\
\hline Latamoxef $(\times 1 \mu \mathrm{g} / \mathrm{m} !)$ & 4 & $359 \pm 12$ & $341 \pm 10$ & $386 \pm 4$ & $490 \pm 12^{*}$ & $>600$ \\
\hline Cefamandol $(\times 1 / / \mathrm{g} / \mathrm{ml})$ & 4 & $355 \pm 8$ & $358 \pm 11$ & $376 \pm 15$ & $441 \pm 14^{*}$ & $>600$ \\
\hline Carbenicillin $(\times 1 \mu \mathrm{g} / \mathrm{ml})$ & 4 & $351 \pm 14$ & $338 \pm 6$ & $370 \pm 23$ & $379 \pm 15$ & $423 \pm 23^{*}$ \\
\hline Cefotaxime $(\times 1 \mu \mathrm{g} / \mathrm{ml})$ & 4 & $340 \pm 12$ & $335 \pm 3$ & $350 \pm 15$ & $416 \pm 21^{*}$ & $>600$ \\
\hline $\operatorname{EACA}\left(\times 10^{-2} \mu \mathrm{g} / \mathrm{ml}\right)$ & 4 & $361 \pm 10$ & $383 \pm 2$ & $417 \pm 17$ & $487 \pm 29^{*}$ & \\
\hline Urokinase $\left(\times 10^{-4} \mathrm{U} / \mathrm{ml}\right)$ & 3 & $336 \pm 8$ & & $308 \pm 9$ & $272 \pm 17$ & $185 \pm 27^{*}$ \\
\hline \multicolumn{7}{|l|}{ Rabbit } \\
\hline Latamoxef $(\times 1 \mu \mathrm{g} / \mathrm{ml})$ & 3 & $28 \pm 2$ & $29 \pm 2$ & $29 \pm 1$ & $31+1$ & $30 \pm 3$ \\
\hline Cefamandol $(\times 1 \mu \mathrm{g} / \mathrm{ml})$ & 3 & $28 \pm 1$ & $28 \pm 1$ & $29 \pm 1$ & $30 \pm 1$ & $33 \pm 1^{*}$ \\
\hline Carbenicillin $(\times 1 \mu \mathrm{g} / \mathrm{m} /)$ & 3 & $28 \pm 1$ & $29 \pm 2$ & $28 \pm 1$ & $30 \pm 2$ & $28 \pm 1$ \\
\hline Cefotaxime $(\times 1 \mu \mathrm{g} / \mathrm{ml})$ & 3 & $29 \pm 1$ & $29 \pm 1$ & $30 \pm 1$ & $31 \pm 1$ & $34 \pm 1^{*}$ \\
\hline $\mathrm{EACA}\left(\times 10^{-1} \mu \mathrm{g} / \mathrm{ml}\right)$ & 3 & $28 \pm 2$ & $30 \pm 2$ & $31 \pm 3$ & $42 \pm 2^{*}$ & \\
\hline Urokinase $\left(\times 10^{-3} \mathrm{U} / \mathrm{ml}\right)$ & 3 & $27 \pm 1$ & & $26 \pm 1$ & $23 \pm 1$ & $20 \pm 0^{*}$ \\
\hline \multicolumn{7}{|l|}{ Rat } \\
\hline Latamoxef $(\times 1 / \mu \mathrm{g} / \mathrm{ml})$ & 4 & $100 \pm 4$ & $100 \pm 3$ & $99 \pm 2$ & $102 \pm 4$ & $99 \pm 2$ \\
\hline Cefamandol $(\times 1 \mu \mathrm{g} / \mathrm{ml})$ & 3 & $102 \pm 5$ & $104 \pm 8$ & $105 \pm 9$ & $111 \pm 7$ & $137 \pm 17$ \\
\hline Carbenicillin $(\times 1 \mu \mathrm{g} / \mathrm{m} \mid)$ & 4 & $99 \pm 4$ & $97 \pm 4$ & $98 \pm 4$ & $92 \pm 4$ & $88 \pm 10$ \\
\hline Cefotaxime $(\times 1 / \mu \mathrm{g} / \mathrm{ml})$ & 4 & $97 \pm 4$ & $103 \pm 5$ & $103 \pm 4$ & $110 \pm 8$ & $139 \pm 7^{*}$ \\
\hline $\mathrm{EACA}\left(\times 10^{-1} \mu \mathrm{g} / \mathrm{ml}\right)$ & 3 & $99 \pm 3$ & & $102 \pm 4$ & $109 \pm 4$ & $236 \pm 9^{*}$ \\
\hline Urokinase $\left(\times 10^{-2} \mathrm{U} / \mathrm{ml}\right)$ & 3 & $95 \pm 3$ & $89 \pm 4$ & $77 \pm 7$ & $54 \pm 6^{*}$ & \\
\hline
\end{tabular}

EACA, 6-amino-n-caproic acid. AMCHA, trans-4-(aminomethyl)cyclohexanecarboxylic acid. "Mean \pm S.E. "Statistically significant difference compared with 0 concentration $(P<0.05)$. 
blood samples (11).

The effects of the antibiotics on euglobulininduced fibrinolysis were examined by the fibrin plate method. An aliquot $(180 \mu l)$ of the human euglobulin solution in $2.7 \mathrm{mM}$ EDTA buffer ( $\mathrm{pH} 7.8)$ was mixed with $20 \mu 1$ of the test compound solutions. A $20 / 1$ aliquot of the mixture or the preincubated mixture at $37^{\circ} \mathrm{C}$ for $30 \mathrm{~min}$ was put into wells (5 $\mathrm{mm}$ in diameter) of the fibrin plates and incubated at $37^{\circ} \mathrm{C}$ for $20 \mathrm{hr}$, after which the Iysis area was measured. The effective doses of EACA and UK were nearly the same as those obtained with the euglobulin lysis time experiments (Table 2), and LMOX, CMD and CTX reduced the fibrinolytic activity of the human euglobulin fraction at $3000 \mu \mathrm{g} / \mathrm{ml}$ The antifibrinolytic activity of antibiotics found with the human euglobulin test was more pronounced than those with the other system, and the activity was about one tenth that of EACA when compared by the minimum effective molar concentration.

These results suggest that the four antibiotics studied show no fibrinolytic activity but show antifibrinolytic activity only at high concentrations (more than $1000 \mu \mathrm{g} / \mathrm{ml}$ ) which are not achievable in vivo.

\section{References}

1 Marier, R.L., Faro, S., Sanders, C.V., Williams, W., Derks, F., Janney, A. and Aldridge, K.: Moxalactam in the therapy of serious infections. Antimicrob. Agents Chemother. 21, 650-654 (1982)

2 Bruch, K.: Hypoprothrombinaemia and cephalosporins. Lancet i, 535-536 (1983)

3 Uchida, K., Ishigami, T. and Komeno, T.: Effects of latamoxef and methyltetrazolethiol on gammaglutamylcarboxylase activity. Japan. J. Pharmacal. 35, 330-333 (1984)

4 Jenkinson, S.G. and Neu, H.C.: Adverse effects of new cephalosporins. Ann. Intern. Med. 98, 415-416 (1983)

5 Bang, N.U., Tessler, S.S., Heidenreich, R.O., Marks, C.A. and Mattler, L.E.: Effects of moxalactam on blood coagulation and platelet function. Rev. Infect. Dis. 4, s546-s554 (1982)

6 Weitekamp, M.R. and Aber, R.C.: Prolonged bleeding times and bleeding diathesis associated with moxalactam administration. JAMA 249, 69-71 (1983)

7 Bennett, B. and Ogston, D.: Fibrinolytic bleeding syndromes. In Disorders of Hemostasis, Edited by Ratnoff, O.D. and Forbes, C.D. p. 321 , Grune \& Stratton, Inc., London (1984)

8 Néren, 1., Ramstrm, G. and Wallén, P.: Fibrin plate method with reagents purified by affinity chromatography and its use for determination of fibrinolytic and other proteolytic activity in saliva, bile and plasma. Haemostasis 4, 110-124 (1975)

9 Westlund, L.E., Lundén, R. and Wallén, P.: Effect of EACA, PAMBA, AMCA and AMBOCA on fibrinolysis induced by streptokinase. urokinase and tissue activator. Haemostasis 11, 235-241 (1982)

10 Kluft, C., Brakman, P. and Veldhuyzen-Stolk, E.C.: Screening of fibrinolytic activity in plasma euglobulin fractions on the fibrin plate. In Progress in Chemical Fibrinolysis and Thrombosis, Edited by Davidson J.F.. Samana, M.M. and Desnoyers, P.C., Vol. 2, p. 57-65, Raven Press, New York (1976)

11 Hedlin, A.M., Monkhouse, F.C. and Milojevic, S.M.: A comparative study of fibrinolytic activity in human, rat, rabbit, and dog blood. Can. J. Physiol. Pharmacol. 50, 17-21 (1971) 